\title{
ANALISIS SPATIAL THINKING SKILLS MAHASISWA JURUSAN PENDIDIKAN GEOGRAFI UNIVERSITAS PENDIDIKAN GANESHA
}

\section{Qo'idul Umam¹, Ida Bagus Made Astawa ${ }^{2 *}$}

Prodi Pendidikan Geografi, Universitas Pendidikan Ganesha, Indonesia

\section{A R T I C L E I N F O}

Article history:

Received 19 Maret2018

Received in revised form 6 Agustus 2018

Accepted 12 Agustus 2018 Available online 31 Agustus 2018

\section{Kata Kunci:}

mahasiswa, pendidikan

geografi, dan kemampuan

berfikir spasial

Keywords:

students,

geography

education, and

spatial thinking

skills

\begin{abstract}
A B S T R A K
Penelitian ini bertujuan (1) mendeskripsikan tingkat spatial thinking skills mahasiswa Jurusan Pendidikan Geografi (2) menganalisis variasi spatial thinking skills mahasiswa antar semester di Jurusan Pendidikan Geografi. Populasi dalam penelitian ini adalah mahasiswa dari semester II sampai VIII yang berjumlah 79 orang. Rancangan yang digunakan adalah penelitian deskriptif dengan metode pengumpulan data kuesioner yang dianalisis menggunakan analisis deskriptif kualitatif. Hasil penelitian menunjukkan bahwa (1) spatial thinking skills mahasiswa memiliki rata-rata skor 60,89 masuk pada kategori tinggi, sedangkan jika dilihat dari presentasenya dari 51 orang terkategori tinggi $(65 \%)$ dan 28 orang terkategori sangat tinggi (35\%). Hal ini mengindikasikan bahwa desain kurikulum dan pembelajaran di Jurusan Pendidikan Geografi sudah sesuai rencana (2) variasi spatial thinking skills mahasiswa terdapat perbedaan dimana rata-rata yang didapatkan semester II 59,25 (tinggi), semester IV 61,11 (tinggi), semester VI 60,94 (tinggi), dan semester VIII 63,5 (sangat tinggi).
\end{abstract}

\section{A B S T R A C T}

The aims of this research (1) describe level spatial thinking skills students at Geography Education of Department (2) analyze variation spatial thinking skills students between semester at Geography Education of Department. Population of this research is from semester II to VIII. The design of the study was descriptive research, data was collected by questionnaire and analyzed by descriptive qualitative. The results showed that (1) spatial thinking skills students at get average score 60,89 categorized high, when viewed from presentation is 51 categorized high (65\%) and 28 people categorized super high (35\%). This indicates that the curriculum was design and learning in the Geography Education of Department is in accordance with the planned (2) variation spatial thinking skills students is different because the average obtained semester II 59,25 (high), semester IV 61,22 (high), semester VI 60,94 (high), semester VIII 63,5 (super high).

\footnotetext{
* Corresponding author.

E-mail addresses: umam.qoidul@undiksha.ac.id ${ }^{1} \underline{\text { md.astawa@undiksha.ac.id }{ }^{1}}$
} 


\section{Pendahuluan}

Semlok IGI di Semarang (1988) memutuskan bahwa geografi merupakan ilmu yang mempelajari persamaan dan perbedaan fenomena geosfer dengan sudut pandang kewilayahan atau kelingkungan dalam konteks keruangan.

IImu geografi terdapat 3 pendekatan, yakni pendekatan keruangan, pendekatan lingkungan, dan pendekatan kompleks wilayah. Yunus (2016: 41) mengemukakan ketiga pendekatan tersebut tidak muncul secara instan, namun melalui proses dan perkembangan keilmuan yang sangat lama dengan berbagai periodisasi yang telah dilewati. Pengembangan geografi terjadi secara pasti dilakukan oleh akademisi di bidang geografi. Jurusan Pendidikan Geografi merupakan salah satu jurusan yang berada di Universitas Pendidikan Ganesha (Undiksha) yang berfokus untuk mencetak tenaga pendidik maupun peneliti dibidang geografi.

Pada dasarnya untuk mencetak tenaga pendidik yang profesional di bidang geografi saat ini, pemahaman terhadap materi tentang geografi (geographical knowledges) saja tidak cukup untuk dimiliki, melainkan harus memiliki geographical attitude/value, dan geographical skills untuk melengkapinya. Astawa (2016) mengemukakan hal tersebut dilakukan untuk membangun pembentukan insan-insan yang memiliki kemampuan berharmonisasi sosial dan ekologi yang tercermin dengan jelas (instructional effects) pada tujuan geografi sebagai program pembelajaran (Pendidikan Geografi).

Kesepakatan IGI mengamanahkan bahwa pada bidang apapun ilmu geografi diamalkan termasuk dalam bidang pembelajaran, harus berangkat dari esensi geografi yang baku. Memang dari segi substansi, kajian geografi membentang dari obyek/fenomena, litosfer, hidrosfer, atmosfer, biosfer, antroposfer. Substansi yang membedakan adalah (dan merupakan identitas geografi) sudut pandang spasial yang harus diajarkan guru kepada peserta didik (Hadi, 2009).

Kemampuan tersebut membutuhkan spatial thinking skills yang digunakan sebagai landasan dalam melihat fenomena atau permasalahan geosfer yang terjadi. Gersmehl (dalam Lee dan Bernarz, 2012) mendefinisikan bahwa spatial thinking skills merupakan keterampilan yang digunakan oleh seorang geograf untuk menganalisis hubungan keruangan di muka bumi.

Raka Joni (dalam Astawa, 2016) menyatakan bahwa pencapaian tujuan tersebut menuntut paradigma pembelajaran yang mendidik, yaitu pembelajaran yang tidak hanya membuahkan dasar-dasar penguasaan ilmu pengetahuan dan teknologi. Pembelajaran juga sekaligus dapat menumbuhkan karakter yang kuat serta penguasaan kecakapan hidup (soft skills), sehingga tampil sebagai manusia yang penuh kasih terhadap sesama (compassion) serta menjunjung tinggi etika di samping cekatan dan terampil (trengginas) dalam bekerja. Widodo (2015) mengungkapkan bahwa kemampuan untuk berpikir spasial masih sedikit mendapatkan perhatian dalam pengimplementasiannya.

Hal tersebut tentunya sejalan dengan pernyataan Hadi (2012) yang mengatakan bahwa paradigma pembelajaran geografi yang selama ini lebih menekankan pada pengetahuan dan keterampilan spasial serta lingkungan harus direorientasi kepada kemampuan berpikir spasial. Kelemahan mendasar dari aspek kognitif spasial dan keterampilan adalah tidak terbangunnya pisau analisis yang dapat digunakan untuk menghadapi segala problem spasial.

González \& Pascual (2016) mengemukakan bahwa saat ini pemahaman geografi didapatkan secara parsial dan tidak lengkap sehingga dengan penggunaan 
spatial thinking skills akan membantu secara komprehensif melihat variasi atau perbedaan di lingkungan sekitar. Kemampuan berpikir spasial menjadi bagian penting yang harus dimiliki oleh individu sebab dengan adanya kecakapan atau kemampuan berpikir spasial analisa yang dihasilkan oleh seseorang dalam memecahkan permasalahan akan lebih komprehensif.

Tabel 1. Presentase nilai mata kuliah yang menunjang spatial thinking skills

\begin{tabular}{ccccc}
\hline \multirow{2}{*}{ No } & \multirow{2}{*}{ Nama Mata Kuliah } & \multicolumn{3}{c}{ Nilai mata kuliah } \\
\cline { 3 - 5 } & & A & B & C \\
\hline 1 & Kartografi & $53 \%$ & $46 \%$ & $1 \%$ \\
2 & Penginderaan Jauh & $37 \%$ & $63 \%$ & $0 \%$ \\
3 & Geografi Regional Indonesia & $55 \%$ & $39 \%$ & $6 \%$ \\
4 & Geografi Permukiman & $9 \%$ & $67 \%$ & $24 \%$ \\
5 & Sistem Informasi Geografis & $12 \%$ & $79 \%$ & $9 \%$ \\
6 & Geografi Desa dan Kota & $9 \%$ & $67 \%$ & $24 \%$ \\
\hline
\end{tabular}

Sumber; Sistem Informasi Akademik Undiksha (SIAK) 2018; pemilihan mata kuliah diadaptasi dari buku National Research Council yang berjudul "Learn to Think Spatially"

Mahasiswa Jurusan Pendidikan Geografi sebagai calon tenaga pendidik dibidang geografi tentunya akan memiliki konsekuensi jika tidak memiliki kemampuan spatial thinking skills diantaranya (1) kesulitan dalam menjelaskan berbagai materi geografi kepada siswa-siswa karena kurang memahami fenomena geosfer dalam konteks keruangan, (2) tidak tersampaikannya substansi materi pembelajaran geografi dengan baik, sehingga keadaan tersebut akan menjadikan mata pelajaran geografi semakin termarjinalkan oleh siswa. González (2017) juga mengungkapkan tanpa adanya spatial thinking penyelesaian isu yang kompleks yang dihadapi tidak akan efektif, selain itu seorang individu dapat menjadi ahli yang bekerja dengan software GIS tetapi akan seperti kesulitan dalam berpikir seperti mempertimbangkan permasalahan secara menyeluruh, dan melihat permasalahan dari perspektif keruangan.

Berdasarkan Tabel 1.1 tentang presentase nilai mata kuliah yang menunjang spatial thinking skills dapat dilihat bahwa beberapa nilai mata kuliah didominasi oleh nilai B seperti mata kuliah Penginderaan Jauh (PJ), Geografi Permukiman, Sistem Informasi Geografis (SIG), dan Geografi Desa Kota. Keadaan tersebut tentunya mencerminkan bahwa sesuatu yang mendukung spatial thingking skills mahasiswa terkategori baik. Namun, hal tersebut belum dapat dikatakan secara pasti apakah mahasiswa Jurusan Pendidikan Geografi sebagai calon pendidik dibidang geografi sudah memiliki spatial thinking skills dengan baik atau tidak.

Berkenaan dengan itu menjadi hal yang penting spatial thinking skills mahasiswa Jurusan Pendidikan Geografi harus diketahui secara pasti. Subtansi spasial yang secara tidak disadari selalu berada di sekitar kita berlalu begitu saja, sehingga kenyataan tersebut mendorong untuk dilakukaan pengkajian terhadap permasalahan secara lebih mendalam tentang kemampuan spatial thinking skills mahasiswa Jurusan Pendidikan Geografi.

Berdasarkan uraian permasalahan yang telah dipaparkan maka akan dilakukan penelitian yang disajikan dengan judul "Analisis Spatial Thinking Skills Mahasiswa Jurusan Pendidikan Geografi Universitas Pendidikan Ganesha”. 


\section{Metode}

Metode pengumpulan data yang digunakan adalah kuesioner (angket) dan studi dokumen. Angket akan diberikan kepada subjek penelitian yaitu mahasiswa Jurusan Pendidikan Geografi sedangkan pencatatan dokumen diperoleh melalui pencatatan jumlah mahasiswa yang diperoleh dari HMJ Pendidikan Geografi. Analisis data yang digunakan dalam penelitian ini adalah deskriptif kualitatif.

\section{Hasil dan pembahasan}

Hasil penelitian ditinjau dari rata-rata jawaban per soal menunjukkan bahwa nilai terendah terdapat pada pertanyaan nomor 12 dengan dimensi spatial region yang mendapatkan nilai 2.7 sedangkan rata-rata nilai tertinggi terdapat pada pertanyaan nomor 15 dengan dimensi spatial scale yang mendapatkan nilai 4.65 yang dilihat pada Gambar 1.

Hal ini mengindikasikan bahwa mahasiswa Jurusan Pendidikan Geografi belum sepenuhnya bisa mengekspresikan jati diri geografi dengan baik mengingat pada dimensi spatial region mendapatkan nilai terendah. Maka dari itu, ini menjadi bagian penting yang harus diperhatikan bagi dosen atau mahasiswa untuk memahami lebih detail bagian-bagian dari spatial thinking skills

Hasil rata-rata tertinggi yang terdapat pada dimensi spatial scale membuktikan bahwa dalam pemahaman konsep penerapan skala dalam merepresentasikan permukaan bumi dalam bidang konvensional telah dikuasai dengan baik.

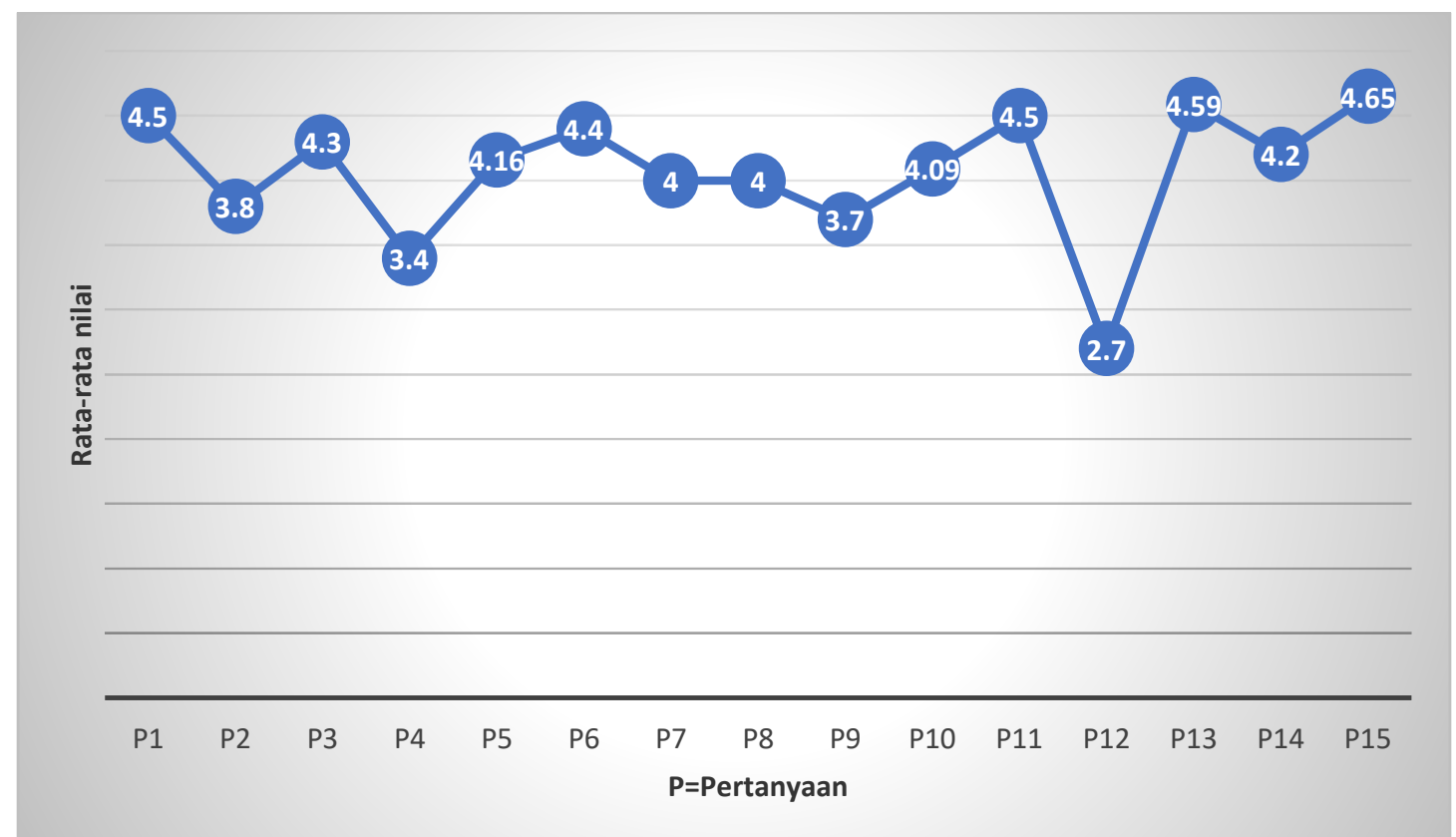

Gambar 1. Hasil analisis data rata-rata jawaban spatial thinking skills per soal mahasiswa Jurusan Pendidikan Geografi

Dilihat dari presentasenya $0 \%$ terkategori sangat rendah, rendah, dan sedang, sedangkan $65 \%$ terkategori tinggi, dan $35 \%$ terkategori sangat tinggi. Namun secara keseluruhan spatial thinking skills mahasiswa Jurusan Pendidikan Geografi memperoleh rata-rata skor 60,89 dengan skala interval 51-62 dan termasuk kategori tinggi yang dapat dilihat pada Tabel 2 dan Tabel 3. Hal ini selaras dengan hasil belajar mahasiswa yang ditunjukkan melalui nilai mata kuliah yang menunjang 
spatial thinking skills yang mana hasilnya didominasi oleh nilai A dan B serta hanya sedikit yang mendapatkan nilai C. Meskipun pada dasarnya setiap mata kuliah yang dirancang di dalam kurikulum Jurusan Pendidikan Geografi selalu didasarkan pada orientasi mahasiswa untuk berpikir keruangan (spatial thinking).

Data tersebut menunjukkan bahwa esensi pendidik dalam mengajarkan berbagai mata kuliah yang didesain dalam kurikulum Jurusan Pendidikan Geografi berjalan sesuai dengan yang direncanakan, artinya selain memang mata kuliah atau kurikulum yang dirancang untuk meningkatkan spatial thinking skills, proses pembiasaan dalam pembelajaran juga harus dilakukan untuk meningkatkan kemampuan spatial thinking skills. Hal ini sejalan dengan penemuan (Ormand dkk, 2014) yang menunjukkan bahwa spatial thinking skills dapat ditingkatkan dengan melalui latihan-latihan atau pembiasaan. Proses pembiasaan tersebut dapat dilakukan melalui pembelajaran yang terjadi di dalam maupun di luar kelas yang didapatkan oleh mahasiswa dan dosen.

Tabel 2. Hasil analisis data spatial thinking skills mahasiswa Jurusan Pendidikan Geografi

\begin{tabular}{|c|c|c|c|c|c|c|c|c|}
\hline \multirow{2}{*}{ No } & \multirow{2}{*}{ Skala interval } & \multirow{2}{*}{ Kategori } & \multicolumn{4}{|c|}{ Semester } & \multirow{2}{*}{ Jumlah } & \multirow{2}{*}{$\begin{array}{c}\text { Presentase } \\
(\%)\end{array}$} \\
\hline & & & II & IV & $\mathrm{VI}$ & VIII & & \\
\hline 1 & $15-26$ & Sangat rendah & 0 & 0 & 0 & 0 & 0 & $0 \%$ \\
\hline 2 & $27-38$ & Rendah & 0 & 0 & 0 & 0 & 0 & $0 \%$ \\
\hline 3 & $39-50$ & Sedang & 0 & 0 & 0 & 0 & 0 & $0 \%$ \\
\hline 4 & 51-62 & Tinggi & 24 & 10 & 11 & 6 & 51 & $65 \%$ \\
\hline 5 & $63-75$ & Sangat tinggi & 4 & 8 & 6 & 10 & 28 & $35 \%$ \\
\hline \multicolumn{3}{|c|}{ Jumlah } & 28 & 18 & 17 & 16 & 79 & $100 \%$ \\
\hline
\end{tabular}

Tabel 3. Hasil analisis data rata-rata spatial thinking skills mahasiswa Jurusan Pendidikan Geografi

\begin{tabular}{cccc}
\hline Variabel & Rata-rata Skor & Skala Interval & Kategori \\
\hline Spatial thinking skills & 60,89 & $51-62$ & Tinggi \\
\hline
\end{tabular}

\section{Variasi spatial thinking skills mahasiswa antar semester di Jurusan Pendidikan Geografi}

Berdasarkan data yang disajikan dalam Tabel 4 dapat dijelaskan bahwa terdapat perbedaan dalam spatial thinking skills mahasiswa antar semester mengingat bahwa semester VIII masuk dalam kategori sangat tinggi. Namun, jika dilihat secara kuantitatif terjadi fluktuasi jika data yang diurutkan mulai dari semester II sampai semester VIII. Penurunan angka terjadi dari semester IV dengan rata-rata skor 61.11 kemudian turun di semester VI dengan rata-rata 60.94 dan kemudian di semester VIII naik menjadi 63.5 .

Temuan ini menjadi menarik karena fakta tersebut menghilangkan asumsi bahwa semakin tinggi semester seorang mahasiswa maka akan tinggi pula spatial thinking skills mengingat mata kuliah yang didapatkan semakin kompleks dan mendalam. Meskipun secara kuantitatif dari temuan ini membuktikan bahwa rata-rata tertinggi diperoleh oleh semester VIII, jika dilihat dari angka yang diperoleh memang tidak terjadi jarak (gap) yang tinggi antar semester. Berdasarkan hal tersebut, dapat didiagnosa penyebab lain dari menurunnya angka spatial thinking skills di semester VI selain sarana dan prasarana, dosen dan desain kurikulum yang diberikan yaitu 
dari faktor internal (pribadi). Hal ini sejalan dengan pendapat (Metoyer dkk, 2015) yang mengungkapkan bahwa konsep spatial thinking skills dibagi menjadi beberapa pendapat salah satunya adalah kelompok nativis yang mengungkapkan bahwa sejak lahir anak secara biologis sudah tentu memiliki level spatial thinking skills, meskipun spatial thinking skills dapat dikembangkan berdasarkan pengalaman-pengalaman.

Selain itu, variasi pengukuran juga dilihat berdasarkan rata-rata hasil jawaban per soal antar semester di Jurusan Pendidikan Geografi yang dapat dilihat pada Gambar 2. Hasil penelitian menunjukkan bahwa rata-rata jawaban terendah terjadi pada pertanyaan nomor 12 yakni pada dengan dimensi spatial region.

Tabel 4. Hasil analisis data spatial thinking skills antar semester mahasiswa Jurusan Pendidikan Geografi

\begin{tabular}{cccc}
\hline Semester & Rata-rata Skor & Skala Interval & Kategori \\
\hline Semester II & 59,25 & $51-62$ & Tinggi \\
Semester IV & 61,11 & $51-62$ & Tinggi \\
Semester VI & 60,94 & $51-62$ & Tinggi \\
Semester VIII & 63,5 & $63-75$ & Sangat Tinggi \\
\hline
\end{tabular}

Rata-rata jawaban tertinggi terjadi pada pertanyaan nomor 13 dengan dimensi spatial connection. Berdasarkan data tersebut dapat dijelaskan bahwa pada dasarnya pola jawaban dari masing-masing antar semester hampir sama secara keseluruhan dan hanya terjadi di pertanyaan 12 yang memiliki perbedaan cukup jauh antara semester VIII dengan semester di bawahnya.

Pola ini menunjukkan bahwa penguasaan materi dari berbagai dimensi spatial thinking skills telah dikuasai dengan baik oleh mahasiswa. Namun, jika melihat pada item secara lebih spesifik rata-rata terendah pada dimensi spatial region diperoleh oleh semester II. Hal ini sangat wajar karena dalam rancangan kurikulum, semester II baru mendapatkan mata kuliah Geografi Regional Indonesia, artinya mata kuliah yang didapatkan belum lengkap (belum tuntas) karena sedang dijalankan saat ini sehingga hal tersebut yang mempengaruhi nilai yang didapatkan pada dimensi spatial region.

Jika melihat rata-rata tertinggi terjadi pada jawaban pertanyaan nomor 13 tentang spatial connection. Variasi jawaban nomor 13 memperlihatkan adanya jenjang nilai antar semester dimana semester VIII memperoleh nilai tertinggi, kedua semester IV, ketiga semester VI dan keempat semester II. Data tersebut menunjukkan bahwa konsep spatial connection yang berbicara tentang keterkaitan antar objek satu dengan yang lain telah dikuasai dengan baik oleh mahasiswa. 


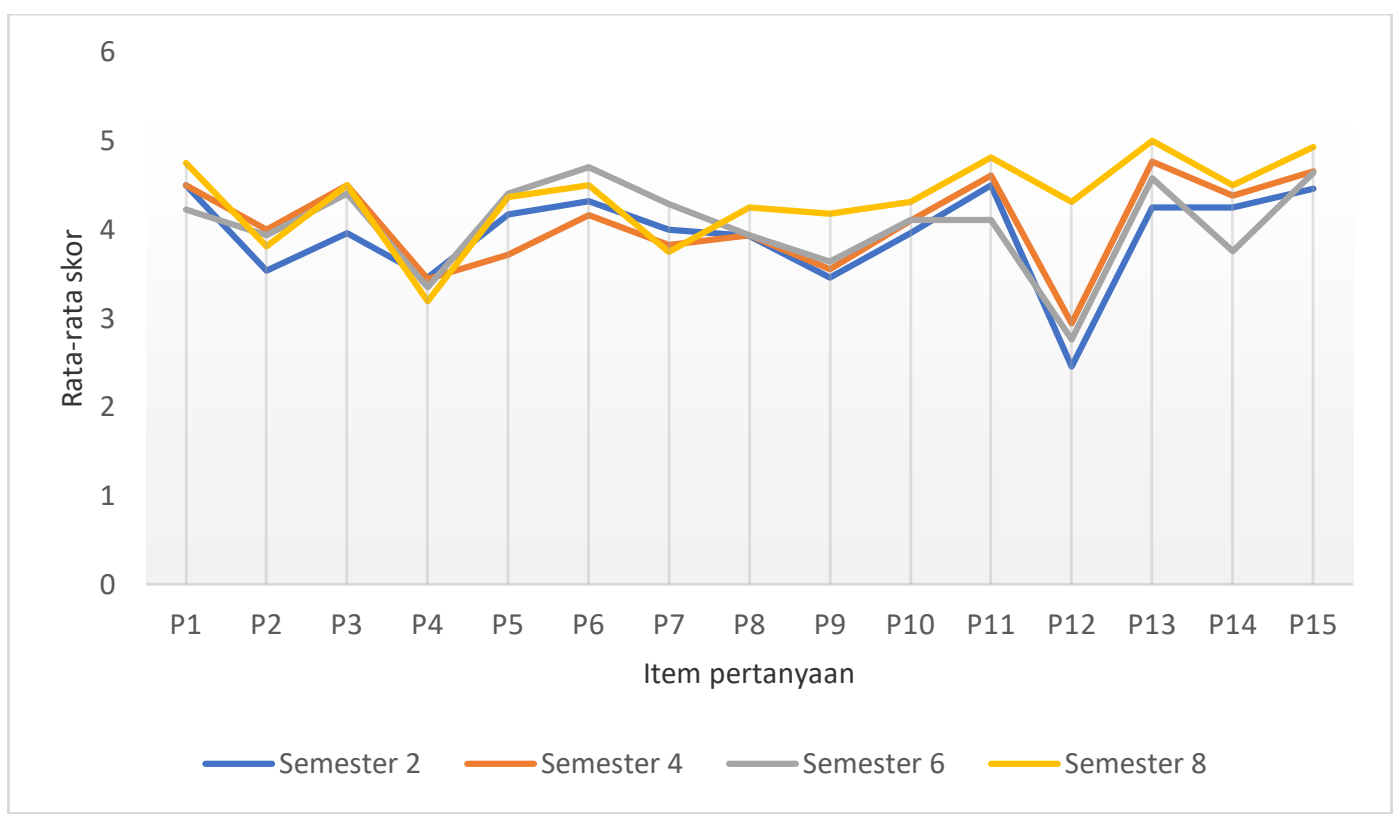

Gambar 2. Hasil analisis data rata-rata jawaban setiap soal spatial thinking skills antar semester mahasiswa Jurusan Pendidikan Geografi

Variasi lain dari spatial thinking skills mahasiswa Jurusan Pendidikan Geografi dapat dilihat dari mata kuliah kompetensi yang diambil oleh mahasiswa. Hasil penelitian menunjukkan bahwa terdapat perbedaan secara kuantitatif dan kualitatif dimana mahasiswa yang mengambil mata kuliah kompetensi pemetaan mendapatkan rata-rata skor 62.27 (tinggi), kependudukan 63.22 (sangat tinggi), dan lingkungan 61.38 (tinggi).

Tabel 5. Hasil analisis data spatial thinking skills mahasiswa Jurusan Pendidikan Geografi dilihat dari mata kuliah kompetensi yang diambil

\begin{tabular}{cccc}
\hline $\begin{array}{c}\text { Mata kuliah } \\
\text { kompetensi }\end{array}$ & Rata-rata Skor & Skala Interval & Kategori \\
\hline Pemetaan & 62,27 & $51-62$ & Tinggi \\
Kependudukan & 63,22 & $63-75$ & Sangat Tinggi \\
Lingkungan & 61,38 & $51-62$ & Tinggi \\
\hline
\end{tabular}

Hal ini tentu menjadi bagian yang menarik mengingat yang terjadi di lapangan justru mata kuliah yang mendukung spatial thinking skills lebih banyak didapatkan oleh mahasiswa yang mengambil mata kuliah kompetensi pemetaan akan tetapi yang mendapatkan rata-rata skor paling tinggi adalah mahasiswa yang mengambil mata kuliah kompetensi kependudukan. Adapun mata kuliah yang menunjang adalah Katografi Terapan, Penginderaan Jauh Terapan, dan Sistem Informasi Geografis Terapan yang hanya diperoleh oleh mahasiswa yang mengambil mata kuliah kompetensi pemetaan dengan mengacu pada kurikulum untuk angkatan 2014 dan 2015. Namun hal tersebut memperkuat temuan sebelumnya tentang variasi spatial thinking skills antar semester dan tentunya sejalan dengan pendapat kelompok nativis. 


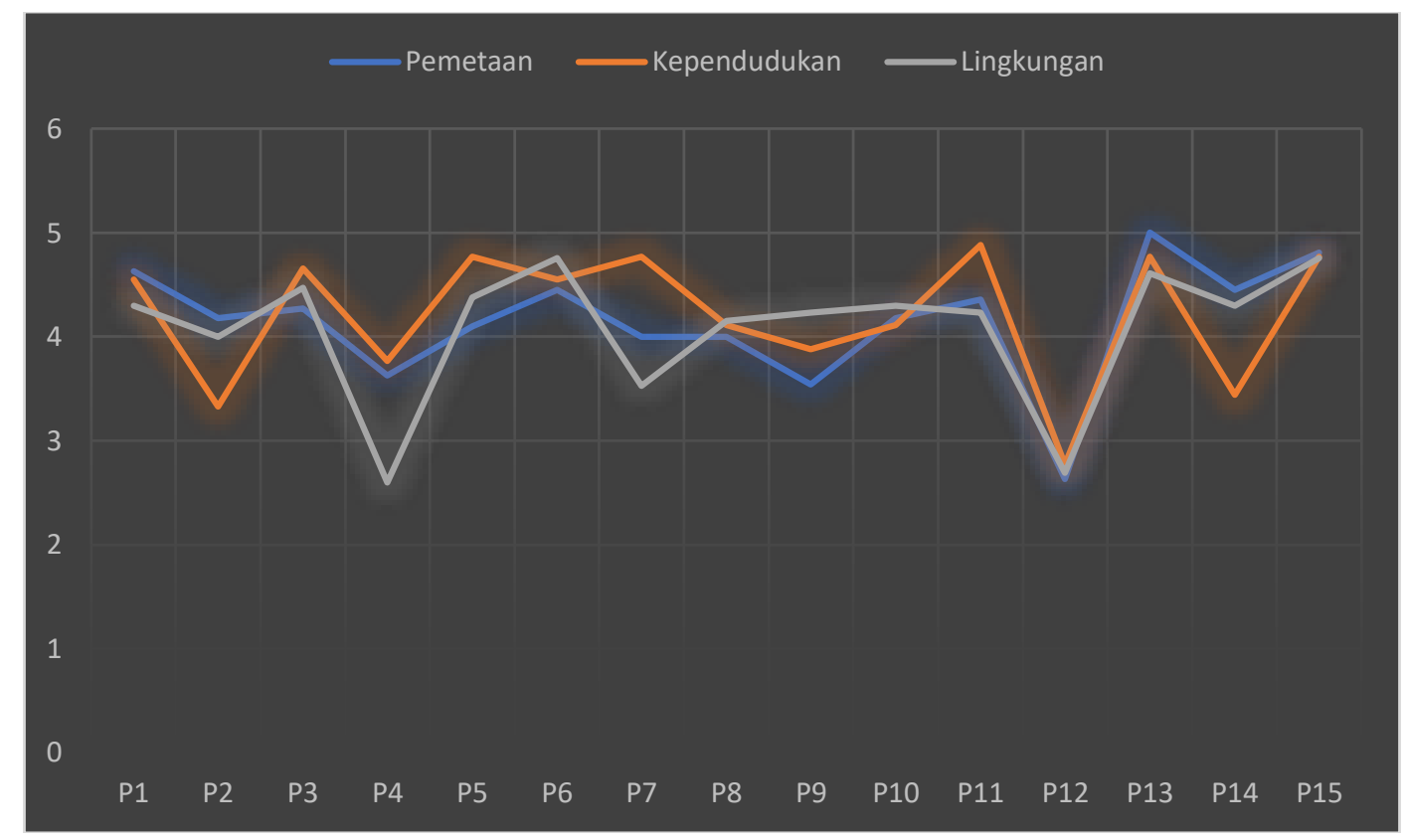

Gambar 3. Hasil analisis data rata-rata jawaban setiap soal spatial thinking skills antar mahasiswa yang mengambil kompetensi Pemetaan, Kependudukan dan Lingkungan

Hasil penelitian ini memperlihatkan bahwa beberapa dimensi dalam spatial thinking skills perlu dipahami secara mendalam dengan penekanan-penekanan konsep yang ada di dalamnya. Hal ini sejalan dengan hasil penelitian Lee \& Bednarz (2012) yang mengungkapkan bahwa beberapa dimensi dalam spatial thinking skills lebih menantang dibandingkan dimensi lain dan mendukun argumen bahwa spatial thinking skills dibuat lebih dari satu keterampilan atau kemampuan.

\section{Simpulan dan saran}

Spatial thinking skills mahasiswa Jurusan Pendidikan Geografi rata-rata skor secara keseluruhan mendapat skor 60,89 dengan skala interval 51-62 dan masuk pada kategori tinggi. Namun demikian, jika dilihat dari presentasenya mendapatkan $65 \%$ terkategori tinggi, dan 35\% terkategori sangat tinggi sehingga dapat dikatakan bahwa dosen, proses pembelajaran dan desain kurikulum yang dilaksanakan di dalam Jurusan Pendidikan Geografi sudah cukup baik.

Variasi spatial thinking skills mahasiswa Jurusan Pendidikan Geografi antar semester terdapat perbedaan. Selain itu, dilihat dari mata kuliah kompetensi yang diambil oleh mahasiswa terdapat perbedaan secara kuantitatif dan kualitatif antar kompetensi pemetaan, lingkungan dan kependudukan. Ditinjau dari rata-rata jawaban per soal menunjukkan pola yang mirip dalam penguasaan materi spatial thinking skills yang dimiliki oleh mahasiswa Jurusan Pendidikan Geografi.

\section{Daftar Rujukan}

Astawa, Ida Bagus Made. 2016. Tuntutan Kepada Prfesionalitas Guru Geografi dalam Mencetak Generasi Ber-Spatial Thinking Skill. Makalah disampaikan dalam Seminar Nasional "Menggapai Pendidik Profesional yang Berkarakter dan Kreatif dalam Praksis IImu IImu Sosial dan Pembelajarnnya untuk 
Mencetak Generasi Cerdas dan Berdaya Saing Global" yang diselenggarakan pada hari Kamis, Tgl. 14 April 2016 oleh Fakultas Ilmu Sosial (FIS) Universitas Negeri Malang (UM).

González, María J \& Pascual, María E V. 2016. Strategic Spatial Thinking and Change. European Journal of Geography Volume 7, Number 1:24 - 35, March 2016

González, María Jesús. 2017. Planning, Urban Sprawl and Spatial Thinking. European Journal of Geography. Volume 8, Number 1:32 - 43, February 2017

Hadi, Partoso. 2009. Pembelajaran Geografi dengan Menggunakan Peta. Bahan Pendalaman Konsep dan Prinsip Geografi Disampaikan dalam "Workshop Guru Pemandu MGMP SMA in service 2 Mata Pelajaran Geografi di Semarang, 9-12 November 2009" Program Studi Pendidikan Geografi, Fakultas Keguruan dan Ilmu Pendidikan, Universitas Sebelas Maret

Hadi, Bambang Syaeful. 2012. Remote Sensing Implementation in Learning to Develop Students' Spatial Thinking Skills. Disampaikan pada International Seminar "Utilization of Geospatial Information to Raise Environmental Awareness in Realizing the Nations Character". Tersedia pada http://staffnew.uny.ac.id/upload/132240452/penelitian/remote-sensingimplementation-learning-develop-student-spatial-thinking-skills.pdf diakses pada 2 Mei 2017

Lee, Jongwon \& Bernarz, Robert. 2012. Components of Spatial Thinking: Evidence from a Spatial Thinking Ability Test. Journal of Geography. Vol 111: 15-26

Metoyer K Sandra, Berdnarz W Sarah, Berdnarz Robert S. 2015. Spatial Thinking in Education: Concepts, Development, and Assessment. O. Mun iz Solari et al. (eds.), Geospatial Technologies and Geography Education in a Changing World, Advances in Geographical and Environmental Sciences

Ormand J Carol dkk. 2014. Evaluating Geoscience Students' Spatial Thinking Skills in a Multi-Institutional Classroom Study. Journal of Geoscience Education 62, 146-154 (2014)

Widodo, Bambang Sigit. 2015. Pengembangan Professional Tenaga Pendidik Geografi dalam Meningkatkan Mutu Pendidikan dan Daya Saing Bangsa Indonesia. Prosiding Seminar Nasional "Pemantapan Profesionalisme Pendidik Geografi di Era MEA". Fakultas IImu Sosial, Universitas Negeri Malang (UM); Malang

Yunus, S Hadi. 2016. Metodologi Penelitian Wilayah Kontemporer. Pustaka pelajar; Yogyakarta 